\title{
Which One is Stronger to Affect Innovation Adoption by Balinese Farmers: Government Role or Local Wisdom?
}

\author{
Ni Nyoman Reni Suasih ${ }^{1}$, Ida Ayu Nyoman Saskara ${ }^{1}$, I Nyoman Mahaendra Yasa ${ }^{1} \&$ Made Kembar Sri Budhi ${ }^{1}$ \\ ${ }^{1}$ Faculty of Economic and Business, Udayana University, Denpasar, Bali, Indonesia \\ Correspondence: Ida Ayu Nyoman Saskara, Faculty of Economic and Business, Udayana University, Jalan P.B. \\ Sudirman, Denpasar, Bali, Indonesia. E-mail: iansaskara@gmail.com
}

Received: March 3, 2017

doi:10.5539/jsd.v10n3p93
Accepted: April 13, $2017 \quad$ Online Published: May 31, 2017

URL: https://doi.org/10.5539/jsd.v10n3p93

\begin{abstract}
Bali is a popular tourist destination that still maintain its typical culture in many areas of life, including in agriculture. Basic implementation of the primary sector in this island is based on the local wisdom called Tri Hita Karana or three causes of happiness. Tri Hita Karana consists of Parahyangan, Pawongan, and Palemahan, the harmonious relationship between human and God, fellow human beings, and the environment. Decision-making of farmers to do adoption of innovations always considering compliance with the local wisdom. Agricultural innovation has been developed from the results of research and development by the government. The government has several functions in the agriculture sector, such as: regulation functions, education functions, control functions, supervise functions, and stabilization functions. This study aimed to analyze the effect of the implementation of local knowledge and the role of the government towards the adoption of innovation, and to determine the factors which have a dominant effect on the adoption of modernization. The results showed that both the implementation of local wisdom and government role have positive and significant effect on innovation adoption by Balinese farmers. In fact, the implementation of local wisdom is stronger to affect innovation adoption than government role. Therefore, it is suggested that in the research and development innovation for agriculture, the government and researcher always consider the suitability with local wisdom, so that innovations can be adopted by farmers optimally.
\end{abstract}

Keywords: local wisdom, government role, adoption of innovation, Tri Hita Karana

\section{Introduction}

\subsection{Introduction of the Problem}

One of the institutions that grow and develop agriculture in Bali is Subak. Subak existed along time ago in Bali based on the philosophy of Tri Hita Karana, that's to say Parahyangan (harmonious relationship between man and God), Pawongan (harmonious relationships with fellow human beings), and Palemahan (harmonious relationship between human and the environment). It can be considered a true culture of life (living mechanism) that influence the Balinese way of being, based on religion and Hindu culture. Examples of it in rice cultivation is the implementation of various agricultural ceremony/ritual in since the seed planting until the eve of harvest arrives.

Commencing on June $29^{\text {th }}$, 2012, Subak as the "core" of the agricultural activities in Bali fixed by the United Nations (UN) through the United Nations Educational, Scientific, and Cultural Organization (UNESCO) as World Cultural Heritage (Kemendikbud, 2013). Previously UNESCO recognized three sites in Indonesia as World Cultural Heritage, i.e. Sangiran archeological site and Prambanan temple. Sulistyanto (2012) explains that Indonesia get benefited from the determination of the status as world cultural heritage. The benefits like the restoration of Borobudur temple with the fund from UNESCO and then Sangiran site has become a tourist destination since the management is also assisted by UNESCO.

The determination of Subak as world cultural heritage included in the category of cultural landscape entitled "The Cultural Landscape of Bali Province: the Subak System as a Manifestation of the Tri Hita Karana Philosophy" (Windia and Wiguna, 2013). There are two rules of being World Cultural Heritage, should be used as guidelines in the management and utilization of World Cultural Heritage region, namely authenticity rules (maintaining the authenticity) and sustainability rules (ensure sustainability).

Uniqueness of Subak cultural that has elements of cooperativeness and concept of the Tri Hita Karana is one of the 
determining factors that led to UNESCO recognizes Subak as World Cultural Heritage. Subak Pulagan is one of subak that become WBD which be drained by Pakerisan Watershed, located in the village of Tampaksiring, District Sukawati, Gianyar. Subak Pulagan farmers with degree granting World Cultural Heritage expects no benefits farmers and locals. According to Sarita, et al. (2013), farmers are not too bother with the government's efforts in the establishment of subak as World Cultural Heritage, as long as the degree to contribute and did not give a new burden in their lives. Similarly, Subagia (2011) explained that the views of farmers in a flat tone as World Cultural Heritage actually illustrates that the title does not give a great influence on their lives. The government continues to aggressively fight for the awarding of the subak as one World Cultural Heritage regardless of the condition of farmers.

World Cultural Heritage predicate is expected to be a positive influence on common interests. When viewed from the economic side, the degree World Cultural Heritage is considered to increase revenue and government attention to the situation of farmers Subak Pulagan. There are consequences in addition to gains on World Cultural Heritage predicate, which is to preserve the subak. Sarita, et al. (2013), explain that some of the expectations of farmers in World Cultural Heritage Subak Pulagan after their status can be categorized in three aspects, namely mindset, social and material aspect. Mindset aspect, namely the increasing awareness of the general public in order to preserve the subak, have knowledge of World Cultural Heritage and UNESCO, as well as increased government attention by providing solutions to the problems experienced by farmers in Subak Pulagan. The solutions are expected to include: (1) fund that will motivate the productivity of the land; (2) improving irrigation and physical building water control system; (3) making easy to obtain the needs of production and marketing of the yields; (4) simakrama in order to increase farmers' income; (5) training that can improve the performance of farmers; (6) a program of scholarships for the children of farmers who excel; and (7) the repair and improvement of infrastructure such as subak roads. Furthermore, the social aspect is no conflict among members of subak and between subak to subak, their solution to suppress land conversion, and provision of interaction space. Aspects of material that is free of property tax, subsidization of production facilities and other conveniences, as well as adequate irrigation water and irrigation networks, and physical facilities cared for and treated also. Related conveniences expected in Subak Pulagan farmers, namely: (1) subak land acquisition of land and building tax, which is considered as a form of appreciation to members of subak has been keeping his farm; (2) subsidies or help plant seeds and organic fertilizer; (3) obtain farm loans as capital in the next planting season; (4) ease of obtaining the means of production which correspond to a time trying to farm; (5) access information about the price of unhull and rice; and (6) a guarantee on the risk of crop failure or agricultural insurance.

\subsection{The Importance of the Problem}

Government plays an important role in the development of agriculture in Indonesia, such as regulation role, balancing role and monitoring role. Such development role can actualization with developing the farmers institution. The purpose is to increase farmers welfare, considering that farmers were impressed as inferior profession. Issues of equity, marginality and poverty can be easily seen, both in terms of revenues, in terms of employment and in terms of business. Classification society based on such aspects have a generally pyramidal shape with the highest number is the group under which the weak, ie low income, low workers, small entrepreneurs and poor farmers.

Determination of subak as World Cultural Heritage along with several areas in Bali interrelated. These areas is an integral and inseparable in the Cultural Landscape of Bali which has extensive reach $\pm 19,500 \mathrm{Ha}$. World Cultural Heritage Site Cultural Landscape of Bali accentuate the uniqueness of the system is owned by the Bali. Not only covers areas beautiful rice terraces, World Cultural Heritage also include related areas that support the sustainability of the water control system.

One of the five region including part of the World Cultural Heritage site is the landscape subak of Pakerisan watershed consists of three water control system, and which is a favorite area the tourists are Subak Pulagan in Tampaksiring Village. Subak Pulagan, by Central Bank of Indonesia used to be one example area for increased productivity with the organic rice planting method System of Rice Intensification (SRI) based Microbacter Alfa (MA 11). Innovation in agriculture is done considering Subak Pulagan region as a World Cultural Heritage, but the level of soil contamination is quite high.

This study aims to determine the effect of the implementation of local wisdom (the concept of Tri Hita Karana) and the role of government to the farmers' decision adoption of agricultural innovations. In addition, this research also has the aim to determine which one is stronger between the implementation of the Tri Hita Karana concept, and the government role in determining the farmers' decision innovation adoption. 


\subsection{Related Literature}

\subsubsection{Tri Hita Karana as Local Wisdom}

Etymologically, local wisdom consists of two words, namely wisdom, and local. Local knowledge is a local idea that is wise, full of wisdom, good value, embedded and followed by members of the community. According to Sibarani (2012), local wisdom is the idea of the people who come from the noble values of cultural tradition to set the order of a society. Local knowledge can also be defined as cultural values that can be used to set the order of a society in a wise or prudent. Keraf (2002) also explains that the indigenous (traditional) are all forms of knowledge, belief, understanding or insight as well as custom or ethics in life in ecological communities.

Geriya in Sartini (2004) said that conceptually, local wisdom and excellence is the human wisdom that based on values philosophy, ethics, and behavior in ways that traditional institutionalized. Local wisdom is a value that is considered to be good and right so that it can be survive for a long time. Philosophically, local wisdom can be defined as a system of knowledge of local communities/indigenous (indigenous knowledge systems) that are empirically and pragmatic. Empirical because the processed locally society departs from the facts that occurred around their lives. Aiming pragmatic because the whole concept is awakened as the result of thinking in knowledge system is aimed daily problem solving. Local wisdom also relates specifically to the particular culture and reflects a particular way of life of the community (local communities). In other words, local wisdom resides in the local culture.

Subak as an irrigation system in Bali which is based on the philosophy of Tri Hita Karana. Concept of Tri Hita Karana is defined as the three causes of happiness can be achieved by maintaining harmony among the three elements in the Tri Hita Karana, the element are Parhyangan, Pawongan and Palemahan (Mantra, 2006).

\subsubsection{Government Role in Agricultural Sector}

Adam Smith in Hindriks et al (2006) explains that the government has three main roles, namely: (1) maintenance of internal security and defense, (2) conduct judiciary, and (3) provide the goods that are not provided by the private sector. Further, Barton in Hindriks, et al. (2006) outlined that the government has four main roles, namely:

1) The role of resource allocation, include the determination of the absolute and relative size of government in the economy and the provision of public goods and social welfare services for the community.

2) The role of regulators, including the preparation of regulations and procedures necessary to facilitate the business community regarding business activity and private property rights

3) The role of social welfare, include policies that encourage social equality in the country concerned as taxation, social security (transfer payment) and the provision of some public goods for society mixture.

4) The role of macroeconomic management, which facilitate stability in general and the country's economic prosperity through policies to promote stable economic growth, full employment, low inflation, and balance of payments stability.

Further Hindriks et al (2006) concluded that in the modern era, the role of government is more likely to be categorized in the following three areas.

1) Allocation role, the government as a provider of public goods and services.

2) Distribution role, that the government seek the empowerment of low income communities.

3) Stabilization role, which the government is providing various types of subsidies.

In agriculture sector, the government can be considered to have a role and functions in terms regulation, education, control, supervise, and stabilization.

\subsubsection{Innovation Adoption}

Adoption is a mental process in making decisions to accept or reject a new idea. It can be defined as a person's mental processes of hearing, knowing innovation until finally adopted. The decision to adopt an innovation occurs within the individual. Furthermore, according to Mosher (1991), adoption of innovation is a process that is shown, considering and ultimately rejecting or practicing specific innovation.

It turned out that the adoption process is not stopped immediately after an innovation is accepted or rejected. These conditions will change again as a result of environmental influences adoption receiver. Therefore, Rogers (1983) revise his theory of decisions about innovation, namely: knowledge, persuasion, decision, implementation, and confirmation. 
Rogers (1983) explains that the level of innovation adoption depends on the perception of the characteristics of an innovation adopter. Indicators that reflect the implementation of it include: (1) the relative advantages; (2) compatibility; (3) complexity; (4) triability, and (5) observability.

1) Relative advantage or relative advantage of an innovation appraised value of the economy of a new thing that is better or at a lower cost than has been done before, it's called economic benefits, while the technical benefits in terms of prestige and satisfaction (Edwina and Maharani 2010).

2) Compatibility or level of fitness of innovation relates to the extent to which an innovation is considered to be consistent and in accordance with the socio-cultural values and beliefs, or ideas presented previously to the needs of farmers. According to Edwina and Maharani (2010), the suitability of innovation can be divided into compliance with the neighborhood farmers, concerning the procedures for customs, culture or customs value of the farmer; and the need, a desire that is compatible with the conditions of the farmers.

3) Complexity or level of complexity of an innovation is the degree to which an innovation is considered complicated to be understood and applied. According to Edwina and the Empress (2010) the complexity of an innovation distinguished by: (1) the operation of how the use of innovation; (2) facilities and infrastructure, such as the availability of support facilities; (3) the ability of the application of innovation by labor.

4) Triability or can be trying on an innovation by farmers with regard to the limited resources owned by farmers. Edwina and the Empress (2010) explains that farmers tend to adopt innovations if it has been tried on a small scale in their own land, and proved to be better than adopting innovations on a large scale, because innovation involves many risks.

5) Observability means the innovation can be observed by farmers and others. Edwina and Maharani (2010) explains that in order to obtain the trust of farmers, the government must begin to promote innovation that has succeed and has high potential to succeed as expected. An innovation can be observed from several things: (1) the production generated by using innovation; (2) quality generated by innovation; (3) the revenue/cost reductions that are used through the application of innovation.

Adoption in this research is a process since farmers in Subak Pulagan (location of world cultureal heritage) introduced a new thing (system of rice intensification) until they apply (adopt) it. Adoption and decisions taken regarding individual behavior. How quickly process of adoption will depend on the nature of the dynamics of the target, the dynamics of experience, knowledge, social interaction, social communication and social learning.

\subsection{Conceptual Framework}

Syah Putra, et al. (2012) describes the results of research that the elements of local wisdom reflected in the behavior of farmers positive effect on the pattern of farmers' organizations as well as the behavior of farmers in agricultural science innovation adoption. Occurs between the positive synergy outreach activities with local wisdom approach to innovation adoption of paddy where extension workers and community leaders can work well together in setting rice planting schedules as well as in the process of environmental preservation in the District of Montasik. Furthermore, Herting (2007), explained also that trust as a form of local wisdom contribute to the innovation adoption program at the hospital. Yenjabok, et al. (2005) also explains that the culture and local wisdom, the individual factors, geography factors, organizational factors and economic factors affect the process of communication, acceptance of innovation and adoption of innovation. Likewise Suhartini (2009) mentioned that local knowledge is also manifested in the efforts to manage natural resources traditionally, one of which is power adoption or adaptation to the use of simple technology that is appropriate and cost-effective.

Related to the role of the government towards the adoption of innovation, Williams (2016) explains that one of the factors that influence the adoption of agricultural innovations are the incentives given by the government with relative frequency values as much as $51.7 \%$. Ayoade and Akintonde (2012) showed that the study results in the adoption of agricultural innovations, the role of government through price stabilization policies to control market prices, thereby reducing the power of the farmers in the possibility of a loss in the adoption process innovation. Siregar (2010) result of the research showed that the role of instructor and technology adoption in Tasikmalaya regency together in synergy to increase rice production. Similarly Syah Putra, et al. (2012) mentions the role of government agricultural instructor and significant positive effect on innovation adoption of paddy.

Based on the theories, concepts and research results relevant prior art, it can be prepared the conceptual framework of research linkages between local knowledge, the role of government, and the adoption of innovative agricultural program as Figure 1. 


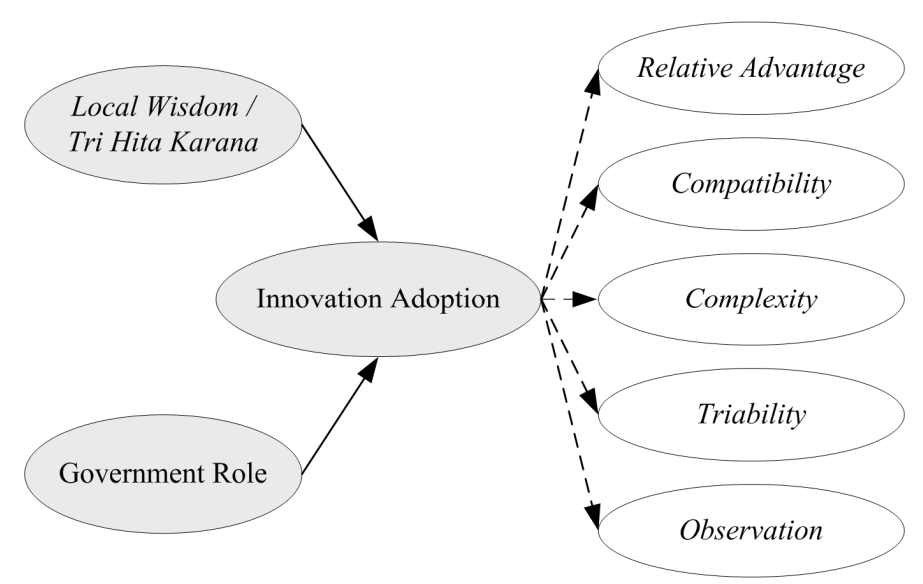

Figure 1. Research conceptual framework

\subsection{Hypotheses}

Based on conceptual framework of this research, there a two hypothesis of this research. First, local wisdom/Tri Hita Karana have positive and significant effect to innovation adoption. Second, government role have positive and significant effect to innovation adoption. Then, to answer the third aim of this research, used to f-square value to know which one between local wisdom and government role is stronger to influence farmers adoption of agricultural innovation in Subak Pulagan.

\section{Materials and Methods}

\subsection{Identify Subsections}

There are three latent variables of this quantitative research. Local wisdom and government role as independent variable. Innovation adoption as dependent variable with second order construct.

\subsection{Farmers Characteristics}

Respondent of this research is farmers at Subak Pulagan in Tampaksiring Village, Gianyar Bali. Subak Pulagan is one of four location of landscape Subak in Bali as World Culture Heritage. Characteristics of farmers at Subak Pulagan can view from farmers age, grade of formal education, and also their land wide range. All of the characteristics as show as Figure 2, Figure 3, and Figure 4.

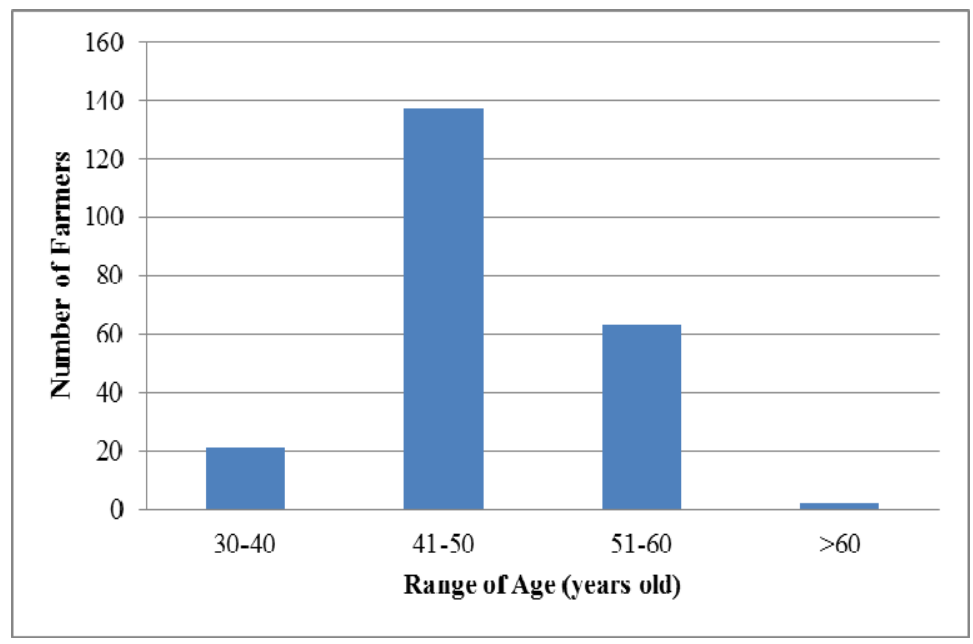

Figure 2. Respondent Age 


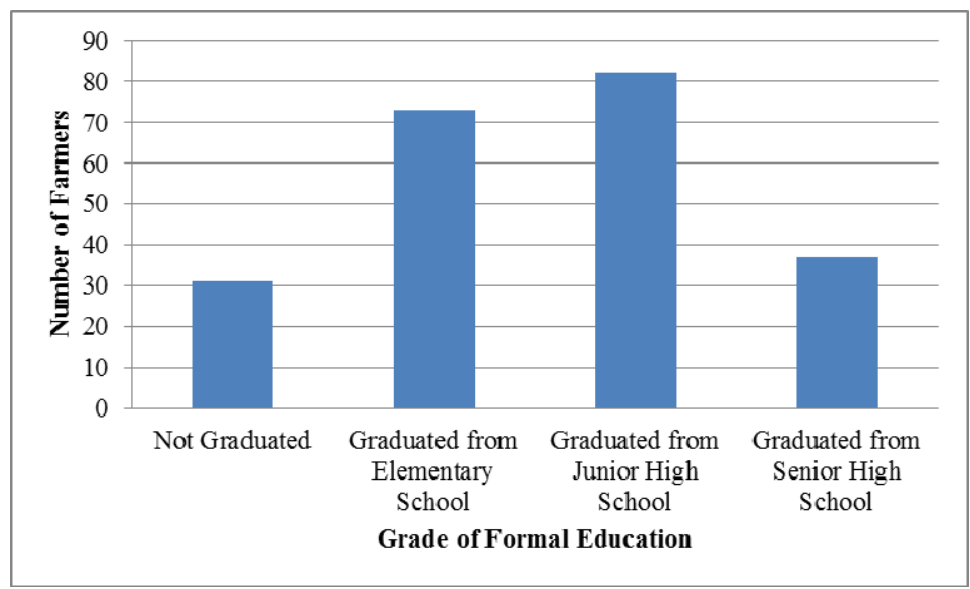

Figure 3. Respondent Grade of Formal Education

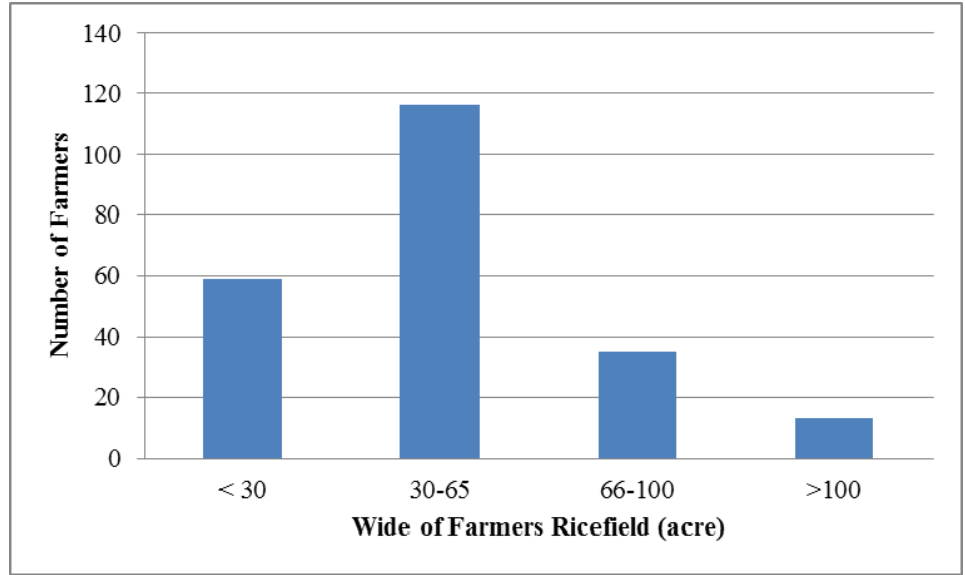

Figure 4. Wide of Respondent Rice Field

\subsection{Sampling Procedures}

Population of this research is 223 farmers at Subak Pulagan. This research is total sampling research, which is use all population as sample, because it's not difficult to collect data from farmers in one area.

\subsubsection{Sample Size}

Because this is a survey research, all population is function as research sample. So, the amount sample of this research is 223 farmers of Subak Pulagan, in Tampaksiring Village, Gianyar, Bali.

\subsubsection{Collecting Data and Analyze}

Data collecting of this research by written questionnaires, observations, and also indepth interview. After collecting data, continued by analyze data with SEM-PLS. First, quality data test (outer evaluation model) with validity and reliability test. Than, inner model measure to know the direct effect of independent variable against dependent variable. Also known the variance effect of the independent variable to dependent effect with $\mathrm{R}$ square value.

\subsubsection{Research Design}

This research is an associative research. This is also a survey research, so the population is also the respondent.

\section{Results}

Structural Equation Modeling (SEM) is a second generation multivariate data analysis method which is used in business research. SEM can test theoretically supported linear and additive causal model (Statsoft, 2013). Wong (2013) also described that SEM can be used in tackling research problem to treat unobservable, hard-to-measure latent variable. 


\subsection{Outer Evaluation Model}

Testing outer models in this study conducted with reliability test and validity test. Variable implementation of local knowledge (Tri Hita Karana) with formative indicator, while the role of government and the adoption of innovative agricultural program with a reflective indicator.

\subsubsection{Reliability Test}

Reliability Test for constructs with formative indicators Among the prevailing assumption that indicator not correlated, then the size of internal consistency (Cronbach's Alpha) is not required to test the reliability of the constructs with formative indicators. Than, construct with reflective indicator as well as show on Appendix, shows that the value of Cronbach's Alpha and Composite Reliability has a value greater than 0.7 so that the construct is Expressed reliable.

\subsubsection{Validity Test}

Validity test conducted to test the discriminant validity (for the formative indicators) and convergent validity test (for reflective indicators). Validity test for constructs with formative indicators, basically a regression relationship of indicators to construct, then the way is a vote to see the value and significance of the regression coefficients of the regression coefficients. The test results as well as Appendix, which shows that the outer weight and the t-value has met the cut-off value of validity. Validity test for constructs with reflective indicators (convergent validity) test can be assessed based on the loading factor indicators that measure the construct. The test results shows that all indicators have a loading factor above 0.7 and above 0.5 AVE based on Appendix. Discriminant validity test, can be assessed based on the cross loading indicator measurements with its construct. The test results in Appendix shows that the correlation indicator with its construct is higher than the correlation of These indicators with other constructs.

\subsection{Analysis of Inner Model (Structural Model)}

Once the model is estimated to meet criteria outer the model, next testing inner models. Structural model in PLS should be evaluated by using the R-square value of the dependent variable and its significance based on the value of $\mathrm{t}$-values on each path. R-square value on the endogenous variables of innovation adoption valued at 0.936. It is mean that $93.6 \%$ of the variation of innovation adoption is influenced by local wisdom/Tri Hita Karana and the role of government. Rated R square of 0.936 (greater than 0.75) for endogenous latent variables in the structural model indicates that the model includes both (Hair, et al., 2013).

The influence of each independent variable on the dependent variable, as in Table 1. As in Table 1, it appears that the direct effect of local wisdom/Tri Hita Karana and the role of governments partially on the adoption of innovation is positive and significant.

Table 1. Path coefficient of direct effect

\begin{tabular}{lccc}
\hline \multicolumn{1}{c}{ Construct } & Coefficient & T Statistics & P Values \\
\hline $\begin{array}{l}\text { Local Wisdom/Tri Hita Karana }(\mathrm{X} 1) \rightarrow \text { Innovation } \\
\text { Adoption (Y) }\end{array}$ & 0.680 & 17.082 & 0.000 \\
Government Role (X2) $\rightarrow$ Innovation Adoption (Y) & 0.301 & 7.657 & 0.000 \\
\hline
\end{tabular}

Furthermore, to determine the effect size of each independent variable on the dependent variable seen from the f-square, as Table 2 .

Table 2. Value of $f$ square

\begin{tabular}{lc}
\hline \multicolumn{1}{c}{ Variable } & f Square \\
\hline Local Wisdom/Tri Hita Karana $(\mathrm{X} 1) \rightarrow$ Innovation Adoption $(Y)$ & 0.909 \\
Government Role $(\mathrm{X} 2) \rightarrow$ Innovation Adoption $(Y)$ & 0.178 \\
\hline
\end{tabular}

Comparison of f-square value of the variable effects of local wisdom/Tri Hita Karana towards innovation adoption was higher than the effect of the government's role to the adoption of innovation. Hair, et al. (2013) explains that the value of the f-square at 0:02, 0:15, and 0:35 can interpret the influence of predictor variables that have a latent 
effect of weak, medium, or large at a structural level. The result showed that the influence of local wisdom/ Tri Hita Karana to the adoption of innovations, including large, while the role of government influence on the adoption of innovations pertained innovation adoption.

\section{Discussion}

\subsection{Direct Effect of Local Wisdom/Tri Hita Karana Against Innovation Adoption}

Local wisdom / Tri Hita Karana proved positive and significant impact on the adoption of innovative agricultural program with a regression coefficient of 0.680 with a probability level of 0,000 . Meaning that if the implementation of Tri Hita Karana is better, then the adoption of agricultural innovations that farmers are also getting better.

Local knowledge of agriculture in Bali was inherited from the ancestors of the people of Bali. Farmers in Bali, especially in Subak Pulagan still retaining the traditions and rituals existing farm. Moreover, most of farmers in Subak Pulagan (61.43\%) aged between 41-50 years, and at that age people in general have stabilized and serious in carrying hereditary culture and customs and religious rituals.

Patinduka (2012) explains that the development of technology based on local wisdom thought it would be easier adopted by the public, because the technology actually comes from the local community, local customs, and local culture, so that the surrounding community also has a passion for keeping local wisdom.

Farming activities in the province of Bali, including in Subak Pulagan not be separated from the context of the history and culture of farming, especially in relation to the social environment of farmers as users of technology and land use strategies. Social environment or often referred to as a cultural ecology which in this context determines the social characteristics of farming and farming strategy and optimizing the technology applied. Social character of the community also plays a significant role in the decision making process related to the adoption and implementation of agricultural technology innovation (Suradisastra and Dariah, 2013).

Pratiwi and Sudrajat (2010) describes the results of the analysis that the education of farmers did not significantly affect the behavior of farmers. Factors level of education attained by the farmer does not affect the behavior of farmers in managing agricultural land. That the higher the level of education attained by the farmers do not behave in a good processing of agricultural land. This can be caused by the way farmers manage agricultural land farmed determined more by learning directly / hereditary and not entirely derived from formal education completed by the farmers.

Local farmer community in Bali is predominantly Hindu and incorporated in subak, the ritual is still positioned as the best way to express adherence to and belief in God. If considered, in every area of wetland is always equipped with a small temple as a place to give offering to God. Even at the level of farmer organizations (subak) are larger temples to perform the ritual worship of God as manifested in the implementation of the agricultural process. This is an implementation of the concept of Parahyangan (the harmonious relationship between human/farmer with God).

Related to the existence of subak organization as a socio-cultural organization that regulates the irrigation system since hundreds of years, can be explained that subak organization formed from harmonious relationships among fellow farmers. Pawongan concept or the harmonious relationship between human beings, is very important in agriculture in Bali, given that farmers in Bali is predominantly small-scale farmers, so farmers will have power when farmers act collectively.

Furthermore, the concept Palemahan (harmonious relationship between human/farmer with the environment) is much less pronounced in the overall agriculture in Bali. The first of the irrigation system is arranged so that the water control system resulting in even distribution of water discharge for all farmers. Furthermore, to maintain soil fertility, farmers also began to increase the use of organic fertilizers. The hope is to maintain the environmental sustainability of agriculture, in accordance with the purpose of Tri Hita Karana that third harmonious relationship will lead to happiness.

\subsection{Direct Effect of Government Role Against Innovation Adoption}

Results of research and analysis of the data suggests that the role of government and significant positive effect on the adoption of innovative agricultural program. The effect is shown by the regression coefficient worth 0.301 with 0.000 probability level. If the role of government is done with the instrument setting function, the function of management, control functions, monitoring functions, and improved balance function, the adoption of innovations will also increase. Adoption of agricultural innovation program consisting of elements of relative advantage, compatibility, complexity, triability, and observation. 
It also expressed Williams (2016) that one of the factors that influence the adoption of agricultural innovations are the incentives given by the government. Ayoade and Akintonde (2012) also concluded that the adoption of agricultural innovations, particularly on women farmers, the government needs to do a price stabilization measures to control the market price so that farmers fear will reduce the possibility of losses in the adoption process innovation.

As noted earlier that one form of government's role in the field of agriculture is subsidies for fertilizer. One positive impact of fertilizer subsidy is to encourage adoption of the technology. It is valid for farmers who do not yet know is whether the benefits of fertilizer, fertilizer impartial including optimal. With the fertilizer subsidy, farmers are not worry for using a new type of technology (type and dose of fertilizer) for the price of subsidized fertilizer (Osorio et al.,2011).

The role of government is to be appreciated with the highest score by farmers in Subak Pulagan is the government's role in the function of management. The Government had committed as the necessary guidance in the implementation of farmers' adoption of innovations in particular to increase agricultural production. Naturally, when later on variable innovation adoption, the farmer puts the highest appreciation in the production of innovation as the highest.

The final goal of agricultural extension is to create the agricultural community independent, professional and entrepreneurial spirit. Turindra (2009) states that raised the implication that the pace of adoption of innovation is pursued through training and development activities by government officials, is determined by.

1) Behavior or committed leadership of the region as the administrator and the man who to responsible for development about how importance of education as a determining factor and facilitating development.

2) Another stakeholder support that allows the public to be able to adopt the innovation offered, notably credit institutions and other agricultural businesses.

3) The public's understanding of the importance of counseling for acceleration of development that requires community participation.

SRI program implementation with jajar legowo planting patterns, the chairman/pekaseh of Subak Pulagan reported that the availability of organic fertilizers is one of the problems encountered. Organic fertilizer is given at the beginning of the program, and to further the farmers need to think about their own way to obtain organic fertilizer. It has carried out efforts to produce its own, but it seems not optimal. While the government provided subsidized fertilizer is not an organic fertilizer. Government through the regulatory function, guidance, control, supervision and counterweight can construct a pattern in addressing the problem of availability of organic fertilizer to support the implementation of the cluster innovation adoption paddy with SRI method and jajar legowo planting patterns.

\subsection{Conclusion}

Local wisdom that has implemented through the concept of Tri Hita Karana, as well as the role of government turned out to be positive and significant effect on the decisions of farmers in conducting agricultural innovation adoption program. Farmers in Bali still keeping to the principles of local which they believe will keep the balance of the environment and sustainability of agriculture and the lives of farmers. Even the results of data analysis also showed that local knowledge has a stronger effect on the farmers' decision to adopt the innovation when compared with the role of government.

The value of local wisdom in Bali related to the agricultural system is still a lot and need to be reexamined. However the implementation of farm life in Bali province will not be released from local elements. Furthermore it is advisable for farmers to continue to preserve the value of local wisdom, local knowledge particularly aims to maintain a harmonious relationship between human and God, human to human, and human and the environment.

\section{Acknowledgments}

The writers sincerely wish to express gratitude to the head of Subak Pulagan in Tampaksiring Village, Gianyar, Bali, Indonesia, for all the help.

\section{References}

Ayoade, A. R., \& Akintonde, J. O. (2012). Constrains to Adoption of Agricultural Innovations among Women Farmers in Isokan Local Government Area, Osun State. International Journal of Humanities and Social Science, 2(8), 57-61.

Edwina, S., \& Maharani, E. (2010). Farmer's Perception About Poultry Processing Technology at Kerinci 
District Kanan, Siak Regency. Indonesian Journal of Agricultural Economics (IJAE), 2(1).

Hair, J. F., Hult, G. T. M., Ringle, C. M., \& Sarstedt, M. (2013). A Primer on Partial Least Squares Structural Equation Modeling (PLS-SEM). Thousand Oaks: Sage.

Herting, S. R. (2007). Trust Correlated with Innovation Adoption in Hospital Organizations. The Innovation Journal: The Public Sector Innovation Journal, 7(2).

Hindriks, J., \& Myles, G. D. (2006). Intermediate Public Economics. MIT Press Book.

Kemendikbud. (2013). Subak as World Culture Heritage. Retrieved from http://kebudayaan.kemdikbud.go.id

Keraff, S. (2002). Environment Ethic. Jakarta: Gramedia.

Mantra, I. B. (2006). General Demography. Yogyakarta: Pustaka Pelajar.

Mosher, A. T. (1991). Getting Agriculture Moving. New York: Frederick A. Praeger, Inc. Publisher.

Osorio, C. G., Abriningrum, D. E., Armas, E. B., \& Firdaus, M. (2011). Who Is Benefiting from Fertilizer Subsidies in Indonesia?. Policy Research Working Paper. WPS5758. East Asia and Pasific Region: The World Bank. https://doi.org/10.1596/1813-9450-5758

Patinduka, J. (2012). Local Wisdom Development at Agriculture Sector to Decrease Global Warming Effect. Retrieved

from http://johnduka.blogspot.co.id/2012/03/pengembangan-kearifan-lokal-di-sektor.html?m=1qQ

Pikiran Rakyat. (2012). UNESCO Acknowledge Subak as World Culture Heritage. Retrieved from http://www.pikirn-rakyat.com

Pratiwi, E. R., \& Sudrajat. (2010). Farmer's Behavior in Manage Agriculture Land at Slide Potential Area (Case Study at Sumberejo Village, Batur District, Banjarnegara Regency, Central Java).

Purwita, I. B. P. (1993). Historical Analysis of Subak at Bali. In I Gede Pitana (Ed.), Subak as Irigation Traditional System in Bali. Denpasar: Upada Sastra.

Rogers, E. M. (1983). Diffusion of Innovations. New York: The Free Press.

Saridewi, T. R., \& Siregar, A. N. (2010). Relationship Between Provider Role and Technology Adoption by Farmers to Increase Rice Productivity at Tasikmalaya Regencies. Sekolah Tinggi Penyuluhan Pertanian. Bogor.

Sarita, A. F., Windia, I. W., \& Sudarta, I. W. (2013). Farmer's Perception About Acknowledgement Subak as World Culture Heritage (Case Study at Subak Pulagan, Tampaksiring District Area, Gianyar Regency). E-Jurnal Agribisnis dan Agrowisata, 2(4).

Sartini. (2004). Analyze of Indonesian Local Wisdom, A Philosophy Analysis. Jurnal Filsafat “Wisdom”. Jilid 37 Nomor 2: 111-120, August 2004.

Sibarani, R. (2012). Local Wisdom: Basic, Role and Method of Verbal Tradition. Jakarta: Asosiasi Tradisi Lain.

Statsoft. (2013). Structural Equation Modeling. Statsoft Electronic Statistics Textbook. Retrieved from http://www.statsoft.com/textbook/structural-equation-modeling/

Subagia. (2011). Planning of Subak as World Culture Heritage, Jatiluwih Farmers doesn't just an object. Retrieved from http://www.beritabali.com

Suhartini. (2009). Review About Local Wisdom in Resources and Environment Management. Retrieved from http://staff.uny.ac.id

Sulistyanto, B. (2012). World Culture Heritage, Bali's Opportunities and Threats. Paper in Sudamala Culture Dialogue.

Suradisastra, K., \& Dariah, A. (2013). Local Wisdom Mapping and Social Capital at Unirrigated Agricultural Field. Hal. 103 - 122. Unirrigated Agricultural Field Prospect to Support Food Sustainability. Badan Litbang Pertanian, Kementerian Pertanian: IARRD Press.

Syah Putra, A. W., Hariadi, S. S., \& Harsoyo. (2012). The effect of Socialization and Local Wisdom to Adoption of Innovation at Montasik District, Aceh Besar Regency. Tesis. Yogyakarta.

Turindra, A. (2009). Factors that Effect Adoption Period. Retrieved from http://turindraatp.blogspot.co.id/2009/11/faktor-yang-mempengaruhi.html?m=1

UNESCO. (2012). Culture Landscape of Bali Province: The Subak System as a Manifestation of the Tri Hita 
Karana Philosophy. Retrieved from http://whc.unesco.org

Williams, A. M. (2005). Research prizes: a new kind of incentive for innovation in African agriculture. International Journal Biotechnology, 7(1/2/3).

Williams, E. (2016). Communication and Adoption Behavour of Information Technology by Rural Farmers in Ebonyi State. Asian Economic and Social Society, 6(1), 14-20.

Windia, W., \& Wiguna, W. A. A. (2013). Subak as World Culture Heritage. Denpasar: Udayana University Press.

Wong, K. K. (2013). Review of the Book Hand Book of Partial Least Squares: Concepts, Methods and Applications. In V. Esposito Vinzi, W. W. Chin, J. Henseler, \& H. Wang (Eds.), International Journal of Business Science and Applied Management, 6(2), 52-54.

Yenjabok, P., Kewthep, K., Pookpakdi, A., \& Intaratat, K. (2005). Agricultural Development Communication for New Theory Concept of His Majesty King Bhumibol Adulyadej: Communication process for the diffusion of new theory concept which result into an adoption by farmers. Kasetsart Journal: Social Sciences, 26, $118-125$.

\section{Appendix}

Loading Factor and AVE

\begin{tabular}{|c|c|c|c|c|}
\hline Variable & Dimention & Indicator & $\begin{array}{l}\text { Outer Loading } \\
\text { to Construct }\end{array}$ & AVE \\
\hline \multirow{3}{*}{$\begin{array}{l}\text { Implementation of Local } \\
\text { Wisdom (X1) }\end{array}$} & & X11 & 0.975 & \multirow{3}{*}{-} \\
\hline & & $\mathrm{X} 12$ & 0.975 & \\
\hline & & $\mathrm{X} 13$ & 0.969 & \\
\hline \multirow{5}{*}{ Government Role (X2) } & & $\mathrm{X} 21$ & 0.899 & \multirow{5}{*}{0.925} \\
\hline & & $\mathrm{X} 22$ & 0.848 & \\
\hline & & $\mathrm{X} 23$ & 0.897 & \\
\hline & & $\mathrm{X} 24$ & 0.873 & \\
\hline & & $\mathrm{X} 25$ & 0.867 & \\
\hline \multirow{12}{*}{ Adoption of Innovation (Y) } & Pelative A dyantage (V1) & Y11 & 0.944 & \multirow{2}{*}{0.879} \\
\hline & Nerauve Auvantage (II) & Y12 & 0.944 & \\
\hline & \multirow{3}{*}{ Compatibility (Y2) } & Y21 & 0.921 & \multirow{3}{*}{0.918} \\
\hline & & Y22 & 0.918 & \\
\hline & & Y23 & 0.940 & \\
\hline & \multirow{3}{*}{ Complexity (Y3) } & Y31 & 0.921 & \multirow{3}{*}{0.936} \\
\hline & & $\mathrm{Y} 32$ & 0.942 & \\
\hline & & Y33 & 0.962 & \\
\hline & Triability (Y4) & Y41 & 1.000 & 1.000 \\
\hline & \multirow{3}{*}{ Observation (Y5) } & Y51 & 0.940 & \multirow{3}{*}{0.902} \\
\hline & & Y52 & 0.916 & \\
\hline & & Y53 & 0.885 & \\
\hline
\end{tabular}




\section{Cross Loading}

\begin{tabular}{ccccccc}
\hline \multirow{2}{*}{ Indicator } & \multicolumn{6}{c}{ Construct } \\
\cline { 2 - 7 } X2 & Y1 & Y2 & Y3 & Y4 & Y5 \\
\hline X21 & $\mathbf{0 . 8 9 9}$ & 0.807 & 0.826 & 0.831 & 0.797 & 0.806 \\
X22 & $\mathbf{0 . 8 4 8}$ & 0.772 & 0.750 & 0.772 & 0.771 & 0.760 \\
X23 & $\mathbf{0 . 8 9 7}$ & 0.810 & 0.791 & 0.814 & 0.774 & 0.815 \\
X24 & $\mathbf{0 . 8 7 3}$ & 0.781 & 0.758 & 0.780 & 0.754 & 0.787 \\
X25 & $\mathbf{0 . 8 6 7}$ & 0.823 & 0.758 & 0.786 & 0.755 & 0.780 \\
Y11 & 0.833 & $\mathbf{0 . 9 4 4}$ & 0.875 & 0.847 & 0.812 & 0.851 \\
Y12 & 0.887 & $\mathbf{0 . 9 4 4}$ & 0.834 & 0.906 & 0.829 & 0.827 \\
Y21 & 0.797 & 0.819 & $\mathbf{0 . 9 2 1}$ & 0.829 & 0.814 & 0.830 \\
Y22 & 0.837 & 0.819 & $\mathbf{0 . 9 1 8}$ & 0.790 & 0.819 & 0.880 \\
Y23 & 0.829 & 0.876 & $\mathbf{0 . 9 4 0}$ & 0.872 & 0.846 & 0.865 \\
Y31 & 0.823 & 0.872 & 0.884 & $\mathbf{0 . 9 2 1}$ & 0.830 & 0.833 \\
Y32 & 0.893 & 0.860 & 0.811 & $\mathbf{0 . 9 4 2}$ & 0.828 & 0.806 \\
Y33 & 0.853 & 0.890 & 0.836 & $\mathbf{0 . 9 6 2}$ & 0.821 & 0.826 \\
Y41 & 0.879 & 0.869 & 0.892 & 0.877 & $\mathbf{1 . 0 0 0}$ & 0.903 \\
Y51 & 0.878 & 0.829 & 0.863 & 0.810 & 0.895 & $\mathbf{0 . 9 4 0}$ \\
Y52 & 0.793 & 0.770 & 0.847 & 0.734 & 0.800 & $\mathbf{0 . 9 1 6}$ \\
Y53 & 0.796 & 0.835 & 0.829 & 0.846 & 0.777 & $\mathbf{0 . 8 8 5}$ \\
\hline
\end{tabular}

Outer Weight and t-value

\begin{tabular}{lccc}
\hline \multicolumn{1}{c}{ Formative Indicator } & Weight & t-Value & p-Value \\
\hline Parahyangan (X11) & 0.359 & 6.466 & 0.000 \\
Pawongan (X12) & 0.362 & 5.303 & 0.000 \\
Palemahan (X13) & 0.306 & 4.386 & 0.000 \\
\hline
\end{tabular}

\section{Copyrights}

Copyright for this article is retained by the author(s), with first publication rights granted to the journal.

This is an open-access article distributed under the terms and conditions of the Creative Commons Attribution license (http://creativecommons.org/licenses/by/4.0/). 